\title{
MST1L Gene
}

National Cancer Institute

\section{Source}

National Cancer Institute. MST1L Gene. NCI Thesaurus. Code C104669.

This gene encodes a non-functional member of the peptidase S1 family. 